\title{
Al Adhan: Documenting Historical Background, Practice Rules, and Musicological Features of the Muslim Call for Prayer in Hashemite Kingdom of Jordan
}

\author{
Tsonka Al Bakri / tsonka@netbg.com \\ Department of Music, Collage of Design and Fine Arts, University of Jordan, JO \\ Mohammed Mallah / mallah.arts@yahoo.com \\ Department of Music, Collage of Fine Arts, Yarmouk University, JO \\ Nedal Nuserat / n.nusiratt@ju.edu.jo \\ Department of Music, Collage of Design and Fine Arts, University of Jordan, JO
}

\begin{abstract}
Adhan, also known as the Islamic call to prayer, is performed five times a day emanating from the spires of every mosque in the world, thus announcing to the faithful their obligation to praise Allah. Throughout the ages, Adhan has commonly been the subject of scholarly work; however, the majority of stated analysis had been performed predominantly in the sphere of theology and linguistics: Daud, 1997; Hilawi, 1984; Khalil and Hafez, 1984; Qadi, 1999; Sadani, 1996, Howting, 2006; Hirschkind, 2006. In Anglo-Saxon academia, the interest has been focused onto similar topics, barely touching on the musical context of the Islamic call to prayer: Choudhuru, 1957; Farmer, 1857; Faruqi, 1987; 1995; Nasr, 1987; Rasmussen, 2001; Waugh, 2005; Frishkopf, 2013. This study tries to establish a connection between different aspects of human culture, namely: Islamic religious tradition and music, presenting two vocal performances of the Adhan as Lahn (melody) in an attempt to show some unique features in the performance of Adhan within the territory of Jordan. Therefore, the first aim of the present study is to demonstrate the Adhan not merely as a part of the theological heritage of Islam, but rather as a cultural phenomenon, part of the Arabic musical heritage. Furthermore, the authors will analyze how the Adhan is taught and how it is performed as per Arabic ancient sources and performance practices. In conclusion, the paper shall analyze the musical characteristics of the two formally recognized Adhan performed within the Hashemite Kingdom of Jordan.
\end{abstract}




\section{Keywords}

Adhan, mu'adhin, maqam, Islamic culture, vocal music, Lahn

\section{Introduction}

This article aims to introduce the historical background of the Adhan and present some musical features characterizing the modern way of performing the Call to Prayer in Jordan. Our belief is that the research can be considered as a step in documenting the transfer of folklore traditions into the body of Islam. The reconstruction of knowledge, connected to the historical path of Adhan and its implementation as a ritual basis upon oral narratives collected form prominent clerics, Islamic religious thought leaders, as well as some ancient sources dating back to the first centuries after the Hijra. The first part of the research will provide historical information about the Adhan. The second will focus on presenting some of the requirements for performing the Adhan and characteristics of the mu'adhin. In conclusion, the paper shall assess specific musical features and especially the use of particular maqamat, forming the specific style in the performance of Adhan in Jordan.

One of the most significant musical manifestations of Islamic culture is the Adhan, summoning the faithful to the mosque, and announcing the mandatory prayers five times daily. As a ritual, it consists of a set of phrases, which are reiterated following an exact pattern (Iqamaah) daily, during a precise point of time. There exist two traditionally recognized etymological definitions of the word Adhan; the first states that the word Adhan is derived from the word Adhine 'to hear/listen', the second, states that the word Adhan is derived from the word Udhun, 'ear'. A similar meaning of the word may be found in the Holy Quran: "a'then hajj, hajj" often interpreted as "Announce the Hajj to the people" (Holy Quran, Surat Al Haj, Ayah, 25). This definition aligns with the common interpretation of the word Adhan as, Announce to the people; alert them that it is time for prayer. Hafetgh bin Hajr had been cited saying, "You may hear the Adhan with both your ears, thus you will know that these are the summons for prayer, these summonses may only be heard through the tongue of man" (Al-Kusy, 1978, 11). Adhan is always performed in Arabic and is based on kalimat, or uttered words. The musical representation of these kalimat can be related to the metaphysical implementation of God's words in spiritual acts of transmission and communication between the ulama (theological scientists), and society in their attempt to perform worship. Islamic rituals lay upon recitation of the Holy texts, namely: the Holy Quran and Adhan that is made of "speech and song" (Frishkopf, 2018, 6). It must be noted that, the etymologic meaning of the word 'sing' in its Western interpretation, leads to semantic error when applied to the actual understanding of Islamic traditional taxonomy concept of the "narrative-melodic" musical representation of the Holy texts. From the Muslim's point of reference, the act of vocal representation embodied into Islamic ritual could be transcribed as non-identical 
semantically to its western analogous. Therefore, the use of 'sing' in the present study should be understood in the context of the applied academic definition, whereas it will be adapted to the similar but sonically dissimilar 'spiritual speech-song' phenomenon in Muslim tradition. Islam as a culture undertakes a special and rather peculiar position with regard to the music. Whereby, the music finds itself constrained and shackled by dogmatic beliefs. On the one hand, music, inter alia, is considered a forbidden art by Islamic dogma. However, on the other hand, Arab people have created their own, unique music. The age-old query looking for the place of music in the culture of Islam is pondered to this day. This dilemma is caused by a large degree of ambiguity in both the Holy Quran and the hadith. However, it is common knowledge that when the Prophet Mohammed arrived to Medina Munawara, he was celebrated with a song performed by the women of the Medina tribes; the song was called "Tala' a al-badr" or "The full-moon rose". Furthermore, there is much evidence in the Hadith (recorded acts, words, and customs of the Prophet) showing that the Prophet was an admirer of music, and that he held no contempt towards it. Al-Ghazali and Al-Ibshiri have both been cited to saying that the "Prophet Mohammed was seen to frequent traveling caravans and musical troupes" (El Kholy, 1984, 20). Regardless of the aforementioned evidence, in time a common misconception was born, affirming the standing of music as a forbidden form of $\operatorname{art}^{1}$. Indeed, music was seen as a manifestation of haram (sin) in the treatises of many ancient Arab philosophers ${ }^{2}$. In reference to these sentiments, a valid comparison can be made between Islamic dogmas concerning music and the early church fathers. ${ }^{3}$ Thus, music in the Muslim world turned into an occult, deeply hidden and encapsulated art, which developed a set of unique characteristics, molding music in a way, which is exceptionally emotional, naturally incorporated with the narrative, linguistic principle of God's risala 4 . The status quo during the early stages of the Muslim culture was to spread the belief of Islam and the word of the Prophet Mohammed. Supported by Islamic perception of sacristy and the assumption that "God is the only source of all the Beauties" (Shikouhi and Yusof, 2013, 364), Muslim ritual has developed into the primary means of religious expression, as well as, religious sentiment in general. The easiest way to present and popularize these feelings was through the medium of music "which alone is able to meet the requirements of human free will and the achievement of divine inspiration" (Toncheva, 1981, 43-44). Herein one may link the historic appearance of the Adhan with the primordial images of Jung, characterized by divinity, unconsciousness, and

1 Music had fallen out of grace, so much so, that musicians were labeled as amoral, and were no longer accepted as witnesses in court (Farmer, 1929, 75).

2 Ibn Abu Al Dunya (9 $9^{\text {th }}$ century) wrote Zam Al Malahi, which forbade all types of music; Jamal Al Din Al Jouzi (12 ${ }^{\text {th }}$ century) wrote a book named Talbis Iblis discussing Sufi music and defining it as Satanic manifestation; Ibn Taymiyah from his side (14 ${ }^{\text {th }}$ century) in Al Sama'a $u$ Al Raqs, shared his believe that music is a Satanic act.

3 "Here there is no need for the cithara, or the stretched strings, or for the plectrum and technique, or for any musical instrument, but, if you like, you may yourself become a cithara by mortifying the members of the flesh and making a full harmony of mind and body" (St. John Chrysostom, 1998, 125-126).

4 According to Islamic doctrine, Holy Quran is a Speech of God (kalimat Allah) sent to Mohammad via risala, (message), delivered through Archangel Gabriel 
autonomy each of which manifest in all cultures similarly. Precisely these images appear to be equivalent to the archaic and collective archetypical representation of God as a creative being and spiritual experience (Samuels, Shorter and Plaut, 1995, 38). Widening the observational lens, we can summary, that one of the major characteristics of Arab ritual music and folklore is to glorify the words and deeds of the Prophet Mohammed and his disciples, thus, helping spread their ideology. Sacral music, as a genre, is one of self-expression through textual and ideological contexts, built upon archaic tunes and chants that appeal on a subconscious level. These tunes derive from pre-Islamic ancient chants $\mathrm{Al} S \mathrm{Sadj}$. There have been studies showing the similarities, both stylistically and structurally, between the early chapters of the Holy Quran, Adhan, and ancient Bedouin incantations (Filishtinski and Shijdaf, 1971, 50). Similar pagan roots could be found in the music of early Christianity (Mc Kinnon, 1987, 20). In the world of Islamic music, one can identify two main streams in the performance of theological texts, tiliaf and Adhan. It is hard to anticipate both performance-renderings without thinking about their actual presentation as ritual; namely their vocal manifestation and theatrical demonstration. It is impossible not to think about the role of voice, as it is the medium, through which one expresses, facilitates, promotes, and reveals secret codes thought sounds. In the case of Islamic music, the voice could be anticipated, as Engelhard describes it "the metaphor for and a cause of existence; it is a means of communication and relationship with spirits, saints and ancestors; and it locates religion in embodied practice, affect, and acoustic space" (Engelhardt, 2018, 1). Through the medium of specific vocal performance, participants in Islam found their way to express spiritual connection, textual content and emotional engagements. The performance of the Holy Quran and Adhan is largely dependent on vocal qualities and the performer's abilities to convey his feeling of piety. Due to this fact, the most prominent sheikhs and members of the Islamic clergy tend to have beautiful voices and musical talent. The second feature mentioned before is the other primordial concept of Adhan; which contains vitality cantered on theatrical dramaturgy. "The Adhan can be distinguished as the first theatrical phenomenon in Islam" (Mallah, 1996, 26). The method of Adhan presentation is conserved to this day in many rural areas. In an attempt to understand the theatric effect of the Adhan one must imagine the scenic background of Arabia, the radiant sun brightening sandy yellowish backdrop, made uneven by the exotic high palm trees, the dull rectangular households glittering in the reflection of the beaming sun; the tall, lean minaret. The figure of the Mu'adhin, standing tall, stern, adorned with pearl white robes, long black beard, holding both hands up towards the turquoise south sky. From the silence, the loud, beautiful, and booming voice of the Mu'adhin comes forth to announce the time for prayer.

\section{Historical Background of the Adhan}

There are two main precedents regarding the genesis of Adhan both of which may be found in the Sunna. Therefore, the time of its inception is no mystery; it is known that 
the Adhan came during al-Hajj al-Kabir, (the magnificent pilgrimage), (The Holy Quran, Surat al Tawbah, Ayah, 3). As for its creation, there are two variants; the first, tells the tale of two of the Prophet Mohammed's disciples, namely, Omar Al Khattab and Abdullah bin Zeid (Sabeq, 1999, 78). They both had had a vision illuminating to them the Call to Prayer "Abdullah bin Zayd Bin Abd Rabbihi, is he, who dreamt the Adhan. This statement is strongly supported by Islamic scholarship" (Al-Mustadrak 1990, 336). Thereafter, the Prophet chose the former slave Bilal Ibn Rabah Al-Habashi, a man renowned for his beautiful and deep voice, to be the first to perform the Adhan among the Mu'adhinun (Al Kusy, 1978, 14-15). There are many fables concerning the validity and practice of Adhan, and they can be traced through compendiums of the hadith and Sunna such as, Mu'arif Al Sunan, At-Tahawi, Sahih Al Bukhari, Sahih Muslim, Jami At -Tirmidhi. ${ }^{5}$ The second retelling of the genesis of the Adhan tells that the Adhan came about as a revelation. It is said in al-Bahr al-Raiq that, the Archangel Gabriel gave the Adhan to the Prophet during a vision he had (Al-Faru, 2004, 302). Thereafter, the Prophet directed Bilal on how to perform the Adhan (Al-Bari 2005, 100). It is necessary to mention that in the Shi'a belief, this is the only accepted retelling of the birth of Adhan, as for the Sunni belief, the tale of Abdullah and Omar is more widespread. During the first year after Hijra, prayer became a mandatory requirement for the faithful Muslim. Thus, came about the question; how is prayer performed? There is historical indication showing that Abdulla Ibn Zaid and Omar Bin Al-Khattab had a vision, wherein the summon should be performed through the voice of man (Abu Daud 1994, hadith 499). The Adhan was first conducted in Medina Munawara shortly after the Prophet Mohammed migrated there. In the beginning the text was improvised, this lasted until Abdullah Ibn Zaid received a vision, wherein he was instructed by an angel to reiterate the Adhan after it (Ibid. 100). Thereafter, the words were approved by the Prophet Mohammed and become entrenched in Islam. Hence, it can be stated that the Adhan went through three specific phases (Al-Ma'arefy, 1982, 14-15).

\section{Rules Regarding the Performance of the Adhan}

There is an exhaustive list of basic rules, which every Mu'adhin must follow while performing the Adhan. In Islamic collages and schools, aspirant sheikhs and mu'adhinun are taught a myriad of canonic treatises regarding the correct pronunciation of the religious texts, including the Holy Quran and the Adhan. ${ }^{7}$ There are some fundamental

5 It must be noted that the most reliable hadith within the Sunna are those of Muslim, Bukhari, Ibn Majal, Darimi, Ibn Hambal, and Tirmidhi.

6 - The call to prayer was not canonized, and was improvised. It is called the Maka'an period.

- Medina'a period, after the Hijra, when Bilal summons the faithful to prayer by using his voice.

- Third period, Abdullah bin Zaid envisions the proper text of the Adhan and it was canonized as exact text.

7 Takwid defines the parameters of proper articulation; idg'ham: assimilation of multiple letters into one sound; tafkhim: emphasis; tarqiq: de-emphasis; maad: elasticity of vowels; and pause: wa'qf (Abd Al Fattah, 2001; Nelson, 2001; Rasmussen, 2001; Frishkopf, 2007). 
rules concerning tilawa, or reading of the text; mushaf, the performance the written pages; qura'a, the phonological readings of the scripts; and ahkam al tajwid the rules of recitation. Historically, there have been various ways of performing Adhan, revealed by Imam Abu Hanifah, Imam Ahmed Bin Hambal, Imam Sha'afee, and Imam Maalik. According to Imam Abu Hanifah, the most noteworthy method of performing the Adhan is the method of Bilal, as he was instructed directly by the Prophet of Allah. These rules are mostly connected with pronunciation, and will not be discussed in depth, as they do not fall within the scope of this paper. The fixed method of pronunciation for the phrases of Adhan and the way they should be sequenced, repeated, and divided by specific breaths is called Tarjee. However, music performance lay on loose guidelines, passed by oral tradition, and manipulated by free variables flying under the radar of references. This mode of verbal transition for performative skills and methods can be described as a powerful encoding of primordial emotion, transmission of venerable precious expertise, and free aesthetic expression. Whereas, performers and the public share similar emotions, traditions, and tastes. By such processes, they mutually interact and affect one another (Akesson, 2012). The role of oral transfer in Islamic culture is well documented by Paterson, who defines the process as follows: "Oral transmission is a sophisticated method used before as well amidst music notation, and it continues to be inextricably incorporated in music, language, tradition and culture" (Paterson, 2015, 35). Likewise, Treitler formulated the same phenomenon as, "[a] process not of reproduction but of reconstruction [of know-how]" (Treitler, 1974, 344), which could be based on the understanding that "melodic stability in ancient times was prevalent idea" (Bronson, 1951, 51). The lack of rigidity in performance of Adhan and Quran could be attributed to the fundamental tradition of improvisation or Taqsim in Arab culture. Rules of taqsim, are also branded with freedom and performative adaptation, lying upon the presence of some major anchor-points and formulas of orientation. This type of improvisation is divided to sections and each section is focused on a single melodic idea. During the taqsim one can locate "departure points, a process of melodic motion, stopping points, opening and closing of the improvised ideas" (Ayari and McAdams, 2003, 166), but mostly the Taqsim can be interpreted as a tool of exchanging feelings between performer and listener. ${ }^{8}$ Therefore, both improvisation tradition plus oral transition from one side, and linguistic frame from the other, define the stability of the coherent system of performance of Adhan and unimpeded passage of sacral wisdom and ancient practice of holy texts through generations.

The most basic performance instructions, passed orally to the modern performers of Adhan are believed to be the same as they were at the beginning of Islam. We will present them as they were collected from different sheikhs and ulama and will be emphasized, as they are necessary for one to truly grasp the principles of performance of Adhan:

8 This is the reason why Arabs differentiate between one who is able to perform taqsim and name him as Mutreb, and one who just sings: Muganni. 
- The beginning of Adhan 'allahu akbar, allahu akbar' is performed in a faster tempo in relation to the second repeat, which is elongated in a more melodic manner. These first phrases are introductory and are performed with mezzo forte.

- When uttering 'ashhadu anna' on the letter 'n' there is a slight stress. There is also an accent on all the consonant letters.

- When pronouncing 'anna' heavy inflection appears on the letter 'n' idg'ham: a silence on the first letter, substituting the first letter with the second letter.

- When performing the sacral word 'Allah', the performer must rely heavily on ornamentation and elongate the vowels.

- A pause must be made between each sentence, allowing the listener to grasp the meaning of what was said.

- Each phrase must be iterated with an incline in the intonation, the first time it is uttered illustrating a question. The repetition must be made with a decline, thus forming the answer.

- When saying 'Mohammadun' an accent is placed on the first letter, to show the importance of the name and its significance in the prayer.

- No letters are to be added or removed; the pronunciation of each word and letter must be flawless. "When calling Adhan stop and wait between the phrases and stretch the words and when you say the Iqammah recite it quickly without braking the breath and pulling the words" (Jami At Tirmidhi and Shaikh Muhammed Jibril, 2005, 69).

- 'Hayya al assalah hayya al alfalah' must be melodically repeated. This phrase is the one to be ornamented the most, in relation to the rest.

- The final two phrases must be sung with a downward movement.

- Every phrase must be followed by a long pause before being repeated. During the first repetition, the phrase is lamented in a tighter tonal spectrum, with less ornamentation, thus it is generally shorter. During the repetition, the phrases are ornamented in a melismatic manner; this is done by expanding the ambitus, whereby often exceeding one octave.

- The form of the Adhan is characterized with contrast, upon which the twelve basic phrases are built. This is achieved by switching the tonal center or using the Tonic Center of varying Maqamat, often being on interval fourth or fifth apart.

- The applied tempo is rubato, in lieu of a free pace, preferably a variable Moderato. Moderation and restraint are basic tenants of the musical performance of Muslim Holy texts. Here one can draw a parallel with the Christian Fathers prohibiting „disorderly cries, 'unnatural shouts' which are abnormal and foreign to Christian worship" (Tabletop book of the Holy-man, 361).

- The Adhan is expected to be recited from a high spot, usually a minaret. The idea behind this rule is so that the voice of the performer will span as wide of a distance as possible. In modern times, the broadcasting is done through loudspeakers atop the minaret.

- When announcing 'hayya al assallah' the upper body of the Mu'adhin must turn to the right, when announcing 'hayya al alfalah' to the left. Custom stemming from the hadith grounds the motivation for this movement. It is pivoted upon the evidence that 
Aun Bin Abi Juhaifa has been cited to have been told, by his father that " $[$ [the father] saw Bilal turning his face left and right when performing the Adhan" (Bukhari, 1986, hadith 608$)^{9}$. Another common customary movement is for the Mu'adhin to place his hands near to his ears when reciting the Adhan. Abu Juhaifa narrated, "I saw Bilal, when performing the Adhan, turning his face left and right while placing his palms near his ears" (Sunan At Tirmidhi, 2009, 197) ${ }^{10}$. Some of the interviewed sheikhs suggested more practical explanation for this custom, explaining it as being a way to sense the vibration coming from vocal chords and sinuses into cranial cavity, thus increasing the capability of producing an adequate vibrato.

- The rhythm of the performance, as many other musical characteristics of the Adhan, has not been inscribed. Thus, providing the Mu'adhin with wide discretion for improvisation. The only rhythmic requirement is that the performer must not hasten through the means of very short rhythmic values.

- Melodic features, as choice of melodic line, maqam, and dynamic, are based on verbal tradition, transferred from the mentor to the student and are not canonized.

Every Mu'adhin must distinguish himself with specific qualities relating to his voice. In Sunan Abu Dawud, (Ketab Al Adab, hadith1,) one can read that "Only the best amongst you should call the Adhan ".There are, however, a set of basic requirements concerning the Mu'adhin:

- To have a beautiful voice,

- To be able to pronounce words and letters properly and eloquently.

- The voice must be powerful with wide tonal amplitude, so that the correct form of sual-jawab, (question and answer) phrase can be adhered to ${ }^{11}$.

- The Adhan is performed mostly by tenors. This custom is promulgated in the hadith. Abdullah Bin Abd Al Tahman Bin Abi Sawsa'ah, who heard it from, Sa'id al-Khadri who cites the Prophet Mohammed to have said the following: "I perceive you to love your herd, if thou shalt be a good shepherd, thou shalt raise thine voice. Thus, your prayer may pierce the souls of man and Djin, for whence, your prayer is heard by the many, the many shalt attest thine faith before Allah" (Al-Nhar, 1994, 42).

- The performer must show emotion and warmth in his performance, so that he may portray the purest sentiment and inspire the faithful.

- The Mu'adhin must differentiate the pitch of the notes and their worth.

- He must be capable of performing qaflat, (cadences), and to improvise.

- The performer must be a Muslim man, sound of mind and body. ${ }^{12}$

- In Sunan Al Kubraa Lil Baihaqi, Ibn Majah and many others, one can find that huge consideration given to the ritual purity and consistency of the Mu'adhin.

9 There is a legend reciting that Bilal would turn when announcing the time for prayer in order to avoid the rocks being thrown at him by the tribe of Quraish. This movement became customary for the portrayal of the struggle through which Islam had gone through.

10 The same method can be found in Sunan Ibn Majah, Al Tahtawi, and others.

11 Tradition of sual-jawab can be traced in Arab folklore, precisely Al Arda songs (Haddad, 2003; Ghawanmeh, 1984; Jargy, 1989)

12 Omar narrates in Elaa As Sunan "There is no Adhan and Iqamaah for ladies." 
The authors of this paper wish to emphasize that, the rules shown herein regarding the requirements towards the Mu'adhin have been collected through extensive research conducted with sheikhs, Islamic clerics, and mentors of the Islamic faith, specifically relating to traditions in Jordan, Iraq, Syria, Lebanon, Palestine, and Saudi Arabia.

\section{Maqam tradition in the performance of Adhan}

Adhan is performed upon the bases of Arab Maqamat (plural of Maqam), (Al Husari, 1965, 114), and all of the Mu'adhinun recite using the Maqamat taught by their mentors. ${ }^{13}$ Over time, resonant feedback leads to the emergence of local performance styles, each characterized by particular configurations of meta-cultural variables, adapted to their ritual environment. This phenomenon stems from two main causal lines. From the Muslim perspective, the text is the main source of knowledge, and its musical incarnation is a discursive expression, which to be freely interpreted. There are no documented notations or precise rules, thus the mode of performance of the Adhan is unconstrained by requirements of reference. Improvisation becomes the method for direct transfer of personal emotion into the payer. The second causal line concerns the recitation of Adhan, which can vary according to the individual reciter, school of the Mu'adhin, cultural micro-area, and local sonic space (local maqamat) (Frishkopf, Nelson $)^{14}$. Undoubtedly, the implementation of particular Maqamat is the result of folkloric traditions, passed down orally through consecutive generations. Herein we will note, "The number of the Arabic maqamat is very large. It has reached 234 modes, however, after the first conference held in Cairo in 1932, the modes were limited to only 52" (Shoura, 2006, 12) $)^{15}$. Therefor, "The repertoire corpus includes about 50 maqamat, seven of which are fundamental once. These are Rast, Bayati, Sikah, Ajam, Nahawand, Hijaz, and Saba" (Qasim and Rassan, 1989, 149). The first to systemize the maqamat was Al Farabi in Ketab al musiqa al kabir, and the modern system was settled by Al Urmai in Kitab fi al musika; Hizir Bin Abdullah in Kitab al Edvar; and Kirsehirli Yusuf in Risale il Musiki. "Maqam in Arab tradition is more than a scale; it is process that includes specific color, melodic movement and forms of improvisation" (Guettat, 1980, 278). Maqam is believed to be one of the important steps in achieving mystical ecstasy ${ }^{16}$ therefore; medieval philosophers connected each Maqam with precise expression or mood. ${ }^{17}$ According to many scholars, namely: Simon Jargy, 1978; Al Barguti, 1979; Boskur Baris, 2008; Taima Habib Hassan, 1971; and Brent Keogh, 2014, among all currently existing Maqamat;

13 The teacher of the Mu'adhin is called muqri

14 The importance of musical practice in Muslim communities is documented by Jankowsky, 2010; Kapchan, 2007; Hirschkind, 2006; Christian, 2004; Mahmod, 2005; Graham and Kermani, 2006,

15 Arabic scales are divided on 24 quarter steps" (Ayari, 2003).

16 Imam Al Ghazali in his book Ihya al Othoum related Sama'a, (listening to music), to mysticism.

17 There is a belief stemming from Sufi mystics, postulating that each of the angels and Prophets has had specific maqam (Hojviri, 1957, 224). 
Maqam Kurd, Saba, Sikah, Rast, Bayati, Hijaz, and Huzam are the most widespread in Arab countries. However, "Bayati is most frequently used in the Middle East, and is widespread in Medina and Saudi Arabia, Maqam Rast and Hijaz can also be heard from popular Mu'adhinun" (Shokouhi and Yusof, 2013, 375). During the performance of Adhan, one Maqam is used as major, thereafter, a secondary Maqam is modulated, after which the Mu'adhin returns to the primary Maqam. Most performers of the Adhan follow this principle of transposition. The lahn is free for interpretation, and is passed down from mentor to student. Every performer bearing the religious duties of the Mu'adhin has the right to interpret the lahn of Adhan and use the Maqam most suitable to his own vocal capabilities and test. He could also choose how or if to transpose to another Maqam. The fundamental rules for performance of Adhan are believed to steam from two of the most famous Mu'adhinun, who lived in the times of Prophet Mohammed. They are made apparent to us through the Hadith, and are namely: Bilal Ibn Rabah AlHabashi and Abdallah Bin Abi Maktoom. Historic sources point to their exquisite vocal capabilities, which were considered awe-inspiring. During the early ages of Islam, two methods for performing the morning Adhan were common. The former is arhan alimsak, which is considered preparation for the latter. Abdullah usually performed the former and Bilal the latter. All following calls to prayer were performed by Bilal. Other distinguished ancient performers of Adhan were Abu Mahthura, Sa'ad al-Qarth, and Ziyad Bin Hareth Al-Sadani, who probably also influenced the performative way of reiterating the Adhan. In modern times, the most famous performers of Adhan hail from the school of Mecca. Even though the Qur'an and Adhan "were revealed in Hijaz, copied in Istanbul and recited in Egypt" (Sayyid, 2003, 24), we have to acknowledge, that nowadays "the Saudi style dominates the performance of Adhan" (Nelson, 2001) ${ }^{18}$.

\section{Adhan in Jordan}

In the Hashemite Kingdom of Jordan, the Ministry of Faith officially chooses the performers of the Adhan. The following list contains the procedural requirements for a person to become a Mu'adhin:

- The person must have Jordanian citizenship.

- The person must have obtained an Undergraduate Degree.

- The person must have completed theological education.

- The person must know a part of the Quran by heart, or at least the final chapter, which is called Amma, and "is considered fundamental" (Al-Kusy, 1978, 181).

A jury designated from the members of the Ministry appoints the Mu'adhin. Every candidate has the right to appear before the commission on a set date and time. On this

18 The following is a non-exhaustive list of the most popular performers of our time: Ali Malla; Hamad bin Mohammad al Daghdeeri; Mohammad Maghribi; Farrouq Hadrawi; Tawfeeq Hadrawi; Tawfeeq Khoukh; Ahmad Khouja; Ahmad Basnawi; Isam Khan; Mohammad Shaker (whom hails from a clan of well-known reciters of the Quran); Ahmad Hahhas; and Majed al Abbas. 
date, the person is interviewed and assessed. The members of the commission take into consideration the applicants vocal abilities, professionalism, and emotional attachment to the faith. A candidate is only chosen where the commission finds that he is capable of performing the Adhan in a beautiful, proper, and melodic manner.

If one would attempt to pinpoint the exact date on which the Adhan was first performed in Jordan, would be met with a herculean task, due to the lack of historical evidences and recorded references. The Treaty of London first recognized Jordan as a formal nation-state in 1946. Before that date, the territory and people of Jordan were a part of various ancient empires such as Babylon, Egypt, Rome, Byzantium, and the Ottoman Empire. Undoubtedly, the appearance of Adhan within the territory of Jordan was caused by the spread of Islam in the region. After the Hijra, within only ten years Islam expanded rapidly throughout the Middle East. This was the time when the Arab tribes dismantled the Byzantine occupation over the lands of Palestine, Syria and Jordan. These countries entered into the Rashidun Caliphate and later into the Umayyad's Empire, becoming part of what we now know as the Arabic Caliphate. As already mentioned, the tradition of musical performance of both Quran and Adhan was based on oral transmission and there are no written documents, or any notation, which could be used to assist in the understanding of Adhan performative development in the Kingdom throughout the ages. ${ }^{19}$ In the Hashemite Kingdom of Jordan, Adhan is broadcasted through the central King Abdullah Bin Al-Hussein mosque. From there it is circulated to all mosques in Jordan, using a designated recording of the Call to Prayer, which is played simultaneously throughout the entire Kingdom. This practice has been applied in the past fifteen years, and is most prominent in urban areas of the country, namely in Amman, Al-Zar'qa (which use one recording), Irbid, and Aqaba (which use a second recording). In earlier times, Adhan would be performed through different recording or live performances. Due to this practice and the proximity of mosques, the broadcast from one mosque would interfere with that of the near mosques. Nowadays mosques are permitted to perform live broadcasts solely during Friday's prayer and must be conducted either by the mosque Sheikh or by a guest reciter. In rural areas, the custom of live performances is still existent to this day.

We would like to present and analyze the two formally recognized versions of the Adhan, which are broadcasted in the four largest cities in Jordan. The first, broadcasted in Amman and Al-Zar'qa, is performed by Imam Hassan Samury. The earliest broadcast of the recording was in the Ashrafieh mosque of Amman during the year 1968. The second, was broadcasted in the University of Irbid's mosque, and was performed by Imam Ma'mun during the same year.

19 First recordings of the Adhan are found in Egypt onto phonogram discs dated to the early twenty century, as well as, radio broadcasting from 1920-1930 (Racy, 1976; Rizk, 2004; Frishkopf, 2007). In Jordan, recording of Adhan starts in 60s and 70s of the twenty century, and the performance method used in these broadcasts is followed up to this date. 
The following notation contains the note transcription for the first Adhan:
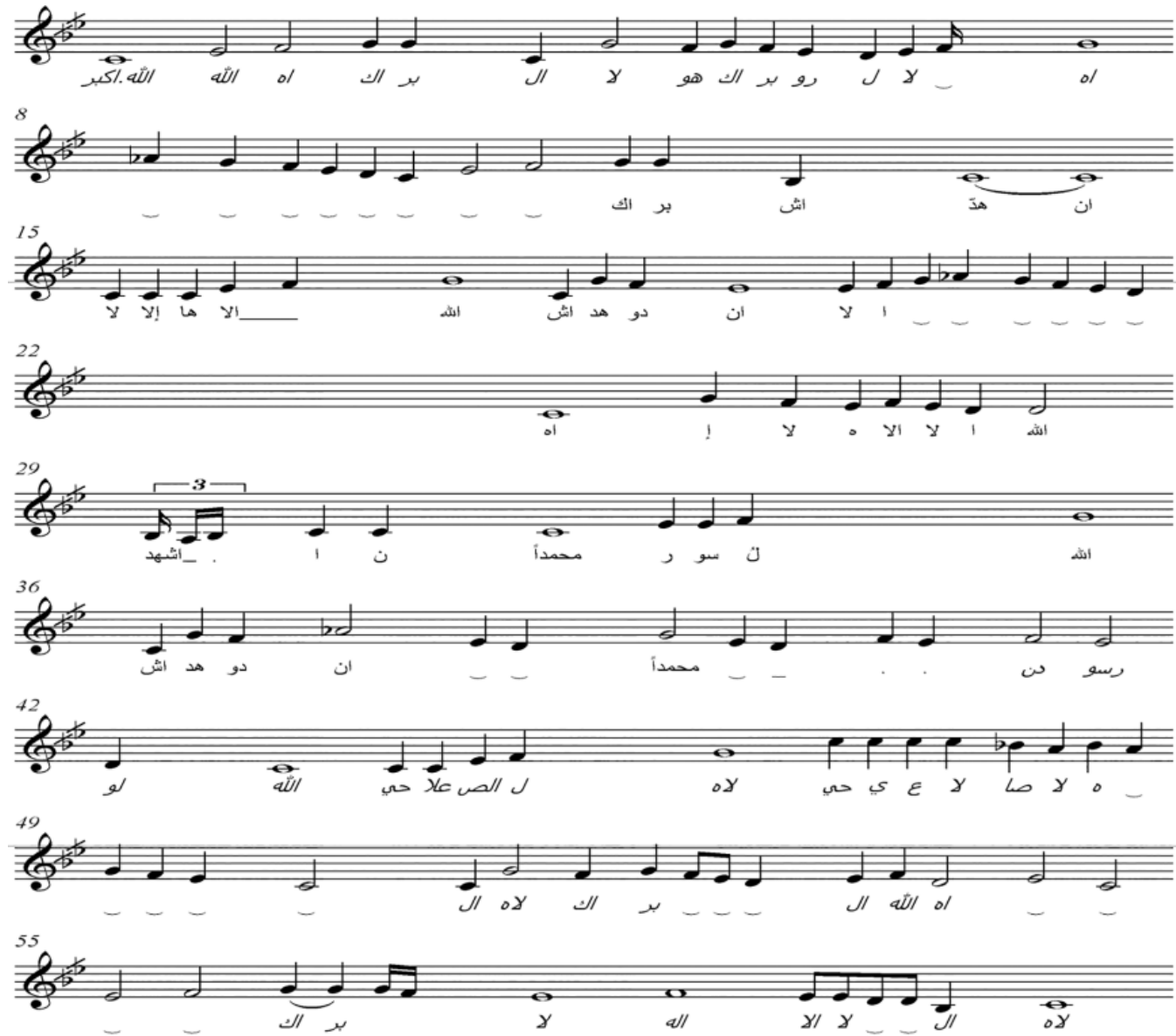

Ex. 1 Transcription of Adhan broadcasted in Ashrafiieh mosque of Amman during the year 1968 and in Al-Zar'qa, performed by Imam Hassan Samury.

This Adhan begins in Maqam Rast, which contains a decline of $E$ kar flat (E quarter flat) and B kar flat (B quarter flat). Maqam Rast is compound of two tetrachords, the first is called Jins Rast, at C key, and the second is Jins Rast at darajet Noa, or G key. There is an aspect of inter connectedness between the two tetrachords called Fasel tanini (major second). 


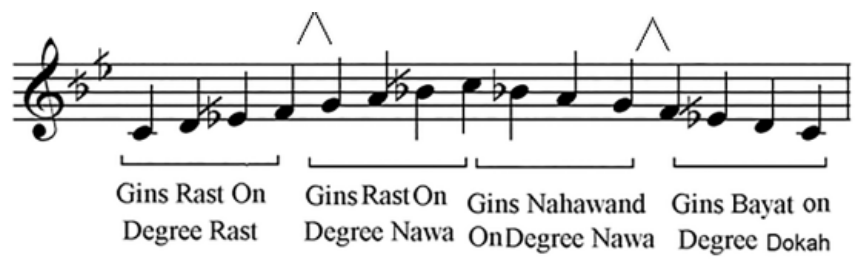

Ex. 2 The structure of Maqam Rast.

The recitation begins at middle $\mathrm{C}$, the Tonic of Maqam Rast. The first phrase develops through on interval minor sixth to A flat, with a steady motion, leaps and skips are avoided until reaching the Dominant G. The second phrase Ashhadu an lā ilāha illāa allāh begins with the leading note B al Ourak. In this phrase, a number of fermata notes can be noticed; they are placed on Tonic, Dominant, Super Tonic, and Mediant. It is precisely through these fermata notes that modulation is achieved, in this case to maqam Nahwand. The mentioned degrees are interpreted as ad libitum, throughout a time in which the performer improvises and ornaments the melody. In the third phrase ashhadu anna Muhammadan Rasul Allāh one may notice acceleration in the rhythm, thus widening the tone volume to A under middle $\mathrm{C}$, otherwise known as al-Osheiran. Furthermore, the long value notes are used for timings when the reciter is able to apply ornamentation. The fourth phrase hayya 'alașalāt widens the ambitus even further reaching the $\mathrm{C}$, second octave, otherwise known as al-Kardan. The tonal range is adhered to until the end of the Adhan. The main characteristics of the Adhan can be summarized as:

- Steady motion. Avoidance of large interval leaps. The largest hops are between Tonic and Dominant.

- Melodic contour: generally undulating with gradual ascending or descending, according to the idea of sual-jawab tradition.

- The ambitus is compound minor third.

- The performer takes specific interest in longer note values, which are usually connected to the pronunciation of the name of God and are fully ornamented.

- There is no fixed time signature. The rhythm and metric pulsation are floating, giving the $M u^{\prime}$ 'adhin discretion for musical and artistic improvisation. The rhythmic values are predominantly quarter notes.

- There are plenty of rests and fermatas between phrases, which permit the listener to assimilate and probe every phrase.

- Tempo is moderato

- Texture is monophonic

- Performance is done by tenor.

- Intensity is quite laud

- Dynamic range is between mezzo forte and forte

The following is the notation of the second Adhan: 


\section{الآذان الذي يقام من مسجد الجامعة في مدينة اربد شمال الأردن}
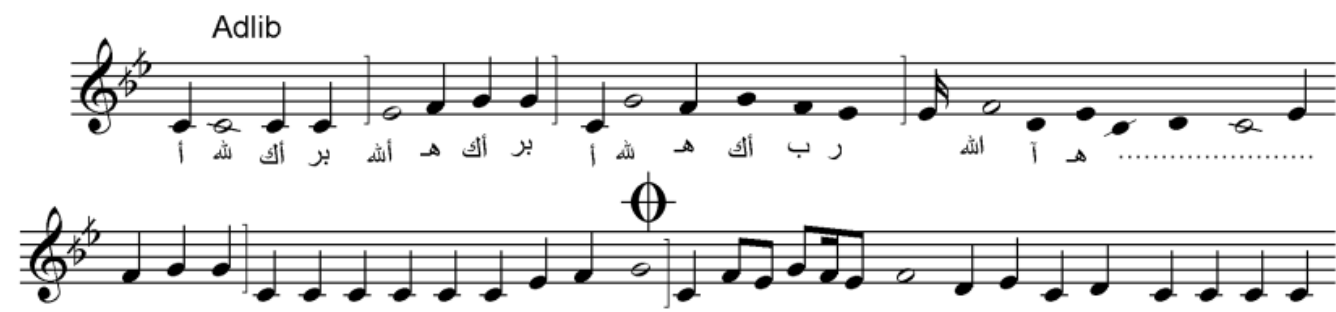

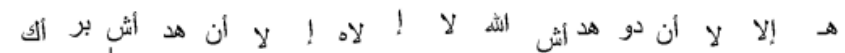
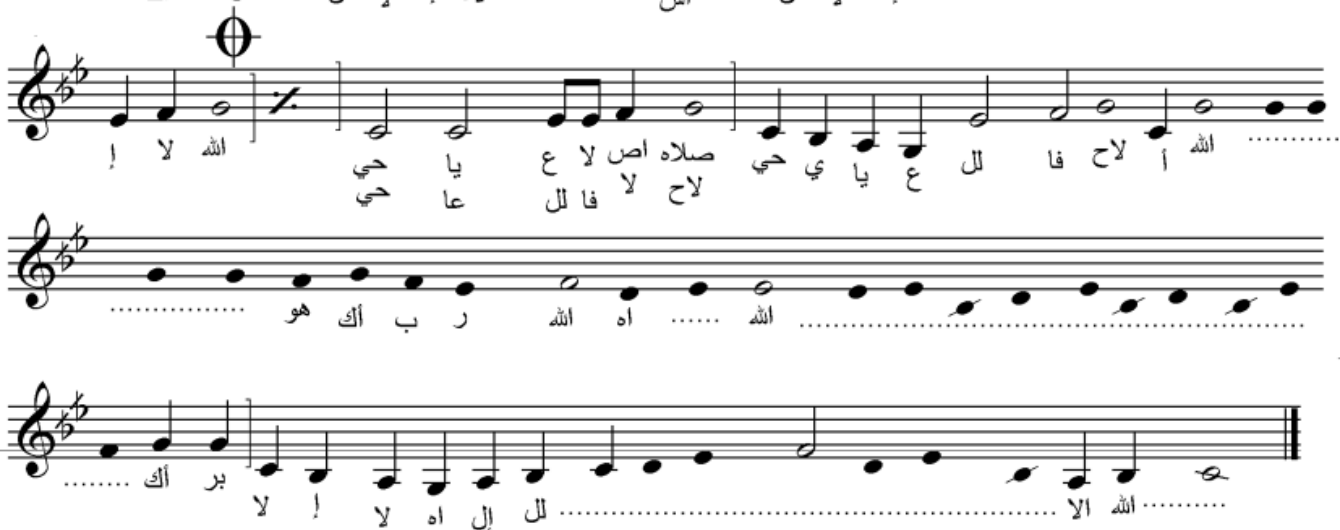

Ex. 3 Adhan broadcasted in the University of Irbid's mosque, performed by Imam Ma'mun in 1968.

The authors would like to highlight that there is no significant variance between the two performances. Both Adhan begin in maqam Rast, with Tonic C, and end on the same Tonic. Both performances are proceeded in a progressive, step-by-step motion, performed with Legato articulation, avoiding fast speed, or short rhythmical values. Both samples are performed in ad libitum, rubato mood. The variance can be found in the tonal ambitus, which in the second case does not surpass the perfect octave, and adheres to the basic maqam Rast with no transposition to another maqam. The Adhan performed in Irbid descends to $\mathrm{G}$, under middle $\mathrm{C}$, otherwise known as al-Yaka'a, however, it does not reach a wider tonal spectrum than one octave.

When uncovering any unique feature of the Adhan performances, one must recognize the specific style in accordance to the local archetype; otherwise, it's geographic connotation. Undoubtedly, performance style depends mostly on the mu'adhin's aesthetic taste, the influences from his school, as well as, "the regional customs and demeanors of the province from which the performer hails" (Getta, 1987, 28). In case of the Jordanian Adhan 
style, performance involves deploying stylistic borrowings from the local folklore, Egyptian style, and as of late Saudi style ${ }^{20}$ of recitation of qur'anic texts. Jordan has never been a theological leader in the Middle East; rather it took input from established regional leaders, Egypt and Saudi Arabia. The Gulf model of performance is recognized as simple in its melodic plan; rapid, nasal, melismatic, and emotional, full of weeping and remorse, characterized by use of higher register and maqam Rast (rather than Bayati). The Saudi Mu'adhin is a preacher and an imam (Abd Al Rahman Sudays); it is the reason why focus is mainly upon the text and its expression, in contract of the Egyptian reciters, who often are musicians (Shaykh Mohammed Rif'at). In late twenty century, Saudi style prevailed throughout the Middle East, enforced by petro dollars, mass media influence of the Pan Arab satellites owned by Gulf Countries, as well as, strong propaganda. "Mass media increasingly longed to commercialization of the performance of qur'anic texts, adapting tilawa style as dominant, what also is connected with the powerful promotion of the Saudi style and ideology of New Islam (al Islam al jaded)" (Frishkopf, 2007, 10-12). In contrast, the Egyptian style is characterized by more melodical elaboration onto the text, more decoration, and it is mostly connected with maqam Bayati. The Egyptian style is based on the idea that "Music, mysticism and maqam are the important staples in Islamic mysticism (Abbas Ma'aref, 2005, 308 $)^{21}$. Recently, the influence of Egyptian style, which was the leading style of performance up to the mid-twenty century in Middle East, including Jordan diminished (Frishkopf, 2007; Hamam, 2000; Sayyad, 2003).

Another factor in the local performance of Adhan is the folklore tradition concerning the use of particular maqamat. "Tradition can be understood only genetically, to study its origins and evolution" (Taft, 1986, 14). Among all currently existing Maqamat; Rast, Bayati, Sikah, Hijaz, and Huzam are the most commonly seen scales in the folk tradition of the Levant (Syria, Palestine, Lebanon and Jordan), (Cohen and Katz, 2006, 22). This results due to the fact that "Some ajnas (plural of jins), like Rast, Nahawand, Hijaz, and Bayati are very common occurring in different maqamat, and linked via many pathways to other ajnas" (Abu Shumays, 2013, 33). "Over time Jordanian musicians adopted the well-known Arabic Maqamat, and based their art mostly on $\mathrm{Al}$ Rast, $\mathrm{Al}$ Bayati, $\mathrm{Al} \mathrm{Hijaz,} \mathrm{Al} \mathrm{Saba,} \mathrm{Al} \mathrm{Ajam}$, and Al Jharka, (Hamam, 2010, 60). Therefore, the use of certain maqamat form Jordanian Mu'adhinun can be traced to their exposure to particular maqamat on a regular basis, as well as their familiarity to the audience. In the musical examples presented, one can observe that Maqam Rast is prevalent in the performance of Adhan in Jordan. This cannot be interpreted as a random fact. Mohammed Ghawanmeh in his book "Jordanian songs" presents multiple folk songs in the Maqam Rast (Al Ghawanmeh, 1998, 82-99). In a paper by Tayseer and Mallah regarding Jordanian folk songs, the researchers noted that the three maqamat; Rast, Bayati and Saba are most common to the genre of folk poems in Trans-Jordanian region (Tayseer and Mallah, 2007, 12). Moreover, Maqam Rast

20 The later influence of Saudi style is observed not only in Jordan, but also throughout the Middle East (Vassiliev 2002, 292; Roussillon, 1998, 345; Frishkopf, 2007).

21 Through the Malukan period, Sufi way of understanding the music permeated the performance of qur'anic text in Egypt, by way which music was experienced, and spiritually comprehend (Lane, 1973; Fernandes, 1999; Taylor, 1989; Shoshan, 1993; Frishkopf, 2007). 
is applied in the most samples of widely popular folk songs of Dabke Al Djoufieh, familiar to the region of Jordan and the Levant (Haddad, 2003, 1669-1675). The wild proliferation of maqam Rast in the region is based undoubtedly on the particular local folklore tradition and specific aesthetic preference. This was confirmed by research conducted by Nedal Abaidat, regarding the use of Rast in Jordanian folk songs, in which he discovered that the primary maqam is Rast, which was found to be used in $30.4 \%$ of all recorded samples. We can interpret, that the propagation of Maqam Rast in the area results by virtue of its emotional effect induced upon the listener. In the ancient texts of Al-Kindi and Al-Farabi, who elaborate on the emotional impact of musical scales on the audience, the perception of Rast was associated with manifestation of masculine power and peace (Eolian 1990, 82-84). Al Farabi in Kitab Al Musiqa, tells a story of Maqam Rast wherein it descended from paradise with Adam, and links the sound and expression of Rast with the beauty and purity of Paradise (Al Farabi, 1967). Maqam Rast is generally accepted as one of the most impactful maqams, and is largely implemented in folk, tarab, (urban classical music), and religious music. "Most imams from Madina Monawara and Haram Sharif (Mecca) like Alhadifi, Sdais and Al Mushsinio, read the Holy Quran in maqam Rast. During tajweed most readers start with Rast or Bayati, because these are recognized to be among the most beautiful scales" (Al Bakri and Mallah, 2016, 128). In a study concerning Adhan performance in Jordan, it was found that "[of] fifty recorded live Adhan performances over a period of four weeks, $46 \%$ of the performances were based on Maqam Rast" (Al Ghawanmeh, Al Ghawanmeh, Haddad, and Nussirat, 2017, 3). In live performances and recordings of the most prominent Jordanian Imams, such as Abdulrahman Jaber, Ibrahim Dabash, Muath al Halija, one can notice the general preference towards Maqam Rast.

\section{Conclusion}

In conclusion, the authors would like to highlight the importance of Adhan in the Muslim world, due to it being an inseparable part of everyday life. The research, concerning the performance of Adhan in Jordan, was based on canon law (Shari'a), hadith, Holy Quran, and Sunna. It was mentioned in the earlier chapters, that the Adhan, as a part of Islamic and Arabic tradition, had developed as a free and improvised recreation of a theological idea adorned by music. Furthermore, it has been noted that performance-improvisation is applied on a strictly fixed text, whereby a set of loosely defined rules and standards of practice must be obeyed concerning the musical presentation of the Adhan. It was disclosed that the lack of written rules relating to the musical aspects of the Adhan could be seen as a byproduct of the Arabic tradition for the transference of knowledge in a hereditary manner, orally from the mentor to the student, as well as outgrowth of the local tradition of taqsim. Herein, the reader may find the two formally recognized versions of the Adhan, performed in the largest cities of the Hashemite Kingdom of Jordan. The authors have documented a few quintessential elements, which characterized the performance of the Adhan in Jordan, namely: folklore tradition connected with predominate 
use of Maqam Rast, and simple musical performative style, close the Saudi method of performance. The widespread implementation of Maqam Rast in Jordanian theological space is proof enough for designation of the influence of particular aesthetic taste and local musical impact onto the Islamic ritual; otherwise, the Islamic ritual illustrates its own adaptation in order to suit the preferences of native groups. This finding presents how sacristy of the holy kalimat limits the possibility for wider adjustments in the main text of the Adhan, but the sound and mood of the lahn may adapt toward locality, society, and local taste. In this way, the sonic map of the Adhan is shifted, thus allowing discourse and definition for particular models such as the Jordanian style in performance of the Islamic Call to Prayer.

\section{Bibliography}

ABAIDAT N. Tariqa fi turath il al Ordon, min ili Istiqlal ila liom. PhD thesis, Jordan, Yarmouk University, 2013.

ABBAS MA'AREF. Sharhe advar. Teheran, Mutabbah al Islam, 2005.

ABU DAUD, S. Kitab Al Salah. Hadith 499, Cairo, 1994.

ABU SHUMAYS, S. Maqam Analysis: A Primer, Music. Theory Spectrum, Vol. 35/2, Oxford, 2013.

AKESSON, I. Oral/Aural Culture in Late Modern Society? Traditional Singing as Proffessionalized Genre and Oral- Derived Expression, Oral Tradition Vol; 27/1, 2012.

AL BARGUTI. Al aghani tarathie fil Phalestin u Ordon. Jordan, 1979.

AL-BARI, DAR AL-KUTUB, AL-ILM, 1410, Vol. 2, Kitab Abwab Al-Adhan, Bab Bad'at Al-Adhan, another version: Fourth edition, Dar Al-Ihya' Al- Turath Al- Arabi, The Mutaqqi Hindi from Tabarani from Ibn Umar. Kanz Al-Ummal, (8), No. 23138, 2005.

AL-DIMASHQ', I. Y. Ryad al-Saliheen, Beirut. Dar el-Hadith, 2004.

AL FARABI. Kitab al muziqa al Kbir, Cairo, Dar al Katib, 1967.

AL-FURU' MIN AL-KAFI, Dar Al-Kutub Al-Islamiyyah, Vol. 3, Bab bada'a Al-Adhan wa Al-Iqamah wa fazlah awath awa bahuma, Hadith 1 and 2. Cairo, 2004.

AL GHAWANMEH, F., AL GHAWANMEH, M., HADDAD, R., NUSSIRAT, N. Adhan as an improvisiation material toward better educational process , International Conference on Musical Cultures, University of Hull, UK, 2017.

AL GHAWANMEH, M. Al 'ahzuja al ordoniia, Dar el-Hadith, Jordan, 1997.

AL GHAWANMEH, M. Abdo Musa, leader and innovator, Al kindki, Amman, 2002.

AL HUSARI, M. Akham Qira'at al Quran al Karim, Cairo, Maktaba al turath al Islami, 1965.

AL-KUSY, O. Kitab al-Uthun, Mu'assasat, Kordoba publising, 12th edition, 1978.

AL-MA'AREFY, Sarhan A. Risale fee al-Uthun, Dar Al Gharb al Islamy, Cairo, 1982.

AL-MUSTADRAK, MAKTABA AL-MATBU'AT AL-ISLAMIYYAH, (3), Kitab Ma'rifa Al-Sahaba, Faza'il Al-Hasan Ibn Ali, Beirut, 1990.

AL-NHAR, A. Kitab al-sala, 4th edition Dar al-Ta'arof, Cairo, 1994.

AL-SAYED, S. Fiqh al-Sana, Dar al-Fath, Cairo, 1990.

AL-SUNAN, Al-Kubra, Dar al Ta'arof, Cairo, 1994.

AYARI, M. Listening to improvised Arabic Music: An Essay in cognitive psychology, Paris, Harmat$\tan , 2003$. 
AYARI M., MCADAMS, S. Aural Analysis of Arabic Improvised Instrumental Music (Taqasim), Music Perception, Vol 2,/1, University of California Press, 2003.

BARIS, B. An Automatic pitch analysis for Turkish, Maqam music, Journal of New music research, Vol. 37/1, 2008.

BRONSON, B. Melodic Stability in Oral Transmission, Journal of the International Folk Music Council, Vol 3, International Council for Traditional Music, 1951.

CHRISTIAN WILLIAM, A. Provoked Religious Weeping in Early Modern Spain, Religion and Emotions: Approaches' and Interpretation. Oxford University Press, 2004.

COHEN, D., KATZ, R. Palestinian Arab Music: A Maqam tradition in practice, University of Chicago Press, 2006.

EL KHOLY, S. The function of music in Islamic culture in the period to 1100, Cairo, 1984.

ENGELHARDT, J. Voicing Religion, Yale Journal of Music and Religion, Vol 4 /1, 2018.

EOLYAN, I. R. Traditional Music of the Arab East. Music: Moscow, 1990.

FARMER, H. A History of Arabian music to 13 century. London: George publisher, 1929.

FERNNANDES, L. The Evolution of Sufi Institution in Mamluk Egypt: The Khanqak. Berlin, 1988.

FILSHTINSKI, I., SHEEDAF, B. Description of the Arab - Muslim culture. Moscow: Nauka, 1971.

FRISHKOPF, M. Mediated Qur'anic recitation and the contestation of Islam in Contemporary Egypt. London, 2007.

FRISHKOPF, M. Paralinguistic Ramification of Language Performance of Islamic ritual. Yale Journal of Music and Religion, Vol. 14/1, 2018.

GETTA, M. Tradition of music culture of the people from Near and Middle East and present times. Moscow: Soviet composers, 1987.

GRAHAM, W., KERMANI, N. Recitation and Aesthetic Reception. Cambridge Companion to the Quran. Cambridge University Press, 2006.

GUETTAT, M. Classical music of Maghreb. Paris: Bernard, 1980.

HADDAD ABD, S. The song of Dabke al Djoufieh. Majallet Abhath al Yarmouk, Vol.19/3B. Yarmouk University Press: Jordan, 2003.

HAMAM, A. Musical life in Jordan. Arua' press: Jordan, 2010.

HAMAM, A. Sufara Al Quran. Markaz al Rayya: Cairo, 2000.

HASSAN, T. H. The maqam phenomenon: An Improvisation technique in the music of the Middle East. Ethomusicology, Vol 15/1, 1971.

HIRSCHKIND, Ch. The Ethical Soundscape: Cassete Sermons and Islamic Counter public. New York: Columbia University Press, 2006.

HOJVIRI, A. Kashir al mahjoub. Teheran: Amir Kabir, 1957.

IBN MANTHUR, J. Lisan al-Arab. Dar Sader: Beirut, 13th edition, 2003.

JANKOWSKY, R. Stambeli: Music, Trans, and Alterity in Tunisia. Chicago University Press, 2010.

KAPCHAN, D. Traveling Spirit Masters: Moroccan Gnawa Trance and Music in the Global Marketplace. Middleton: Wesleyan University Press, 2007.

KEOGH, B. Theory, Representation and Practice of Maqam: Rethinking the representation of the Arab Maqamat, Analytical Approaches to world music Vol.3/2, 2014.

LANE, E. An Account of the Manners and Customs of the Modern Egyptians. Dover Publications, 1973.

MAHMOD, S. Politics of Piety: The Islamic Revival and The Feminist Subject. Princeton: Princeton University Press, 2005.

MALLAH, M. A contemporary analyses of musical education in the Hashemite Kingdom of Jordan. MA Thesis, Unpublished, al-Rouh al Qudus University: Libanon, 1996.

Mazameer Dawood [online], [cit. 12. 06. 2016]. URL: http://www.mazameer.com/vb/showthread. php?t=149224. 
MC KINNON, J. Music in Early Christian Literature, Tatian: Discourse to the Greeks. Cambridge, 1987. Muhammed Saleh al-Munjed [online], [cit. 18. 06. 2016]. URL: http://islamqa.info/ar/100225.

NELSON DAVIS, C. The Qu'ran Recited. The Garland Encyclopedia of World Music, The Middle East. New York, 2002.

NELSON, K. The art of reciting the Qur'an. American University Cairo Press, 2001.

QASIM, R. Some Islamic non-Arabic elements of influence on the repertory of al maqam al Iraqi in Bagdad. Maqam and Raga and Zeilenmelodik, International Council for traditional music, Vol. 28/2, 1989.

PATTERSON, E. Oral Transmission: A Marriage of Music, Language, Tradition and Culture. Musical Offerings, Vol. 6/1, 2015.

RASMUNSSEN, A. The Qu'ran in Indonesian daily life: The Public project of musical oratory. Ethnomusicology $45 / 1,2001$.

ROUSSILLON, A. Republican Egypt interpreted: revolution and beyond. The Cambridge History of Egypt, Vol 2, 1998.

SABEQ, S. Fiqh al Sunna, Dar al fath lil e'lam al arabi Cairo, Vol 1, 1999.

SAHIH BUKHARI. Book of Adhan. Saudi Arabia: Hadith 608, 1986.

SAMUELS, A., BANI SHORTER, Plaut, F. Critical dictionary of analytical psychology, C. J. Jung: London, New York, 1995.

SAYYID, H. Shuyukh al Tilawa. Radio and TV magazine 3581, 2003.

SHAYKH ABU MUHAMMAD JIBREEL. The Call to Prayer, UK, 2005.

SHOKOUHI, M., YUSOF, A. The Influence of Islamic culture and holy Quran on performing arts: relating to sacred vocal music (lahn). $3^{\text {rd }}$ International Quranic Conference, 2013.

SHOURA, N. A Guide to Arabic music. Cairo, 2006.

SHOUSHAN, B. Popular Culture in Medieval Cairo. Cambridge University Press, 1993.

SIRVART, P. Melodic contour in Traditional Music. Journal of the International Folk music council, Vol. 3, 1951.

STRUNK, O. Readings in Music History. St John Chrysostom "Exposition of Psalm 14, revised edition, New York, 1998.

SUNAN AT TIRMIDHI. Book of Salah. Cairo: Hadith 197, 2009.

SUNAN ABU FAWUD. Book of Virtues. Riyadh: Hadith 1, 1992.

Tabletop book of the Holy-man. Volume 1, Moscow: Nauka, 1852.

TAESSER, A., MALLAH, M. Al qaseed in Jordan, Journal of Science and Music. Vol. 16, Jordan, 2007.

TAFT, R. The Liturgy of the Hours in East and West. Collegeville, 1986.

TA'LIQ OF MUWATTA. Sunan Abu Dauod. Dar Ebn Hazem, 2010.

TAYLOR, C. S. The Cult of the Saints in Late Medieval Egypt. PhD theses, Princeton University, 1989.

The Holy Quran. Mujammaa Al Malk Fahed li tibaet al mushaf al sharif, Saudi Arabia, 2009.

TONTCHEVA, E. For „Pletenie Sloves“ music of the Byzantine-Slavic cultural community in the 14th century. Bulgarian Musicology, Vol. 4. Sofia, 1981.

TREITLER, L. Homer and Gregory: The transmission of Epic Poetry and Plainchant. The Musical Quarterly, Vol LX, 3, 1974.

VASSILIEV, A. The History of Saudi Arabia. New York University Press, 2002. 
